\title{
Budvicia aquatica gen. nov., sp. nov.: a Hydrogen Sulfide-Producing Member of the Enterobacteriaceae
}

\author{
ODILE M. M. BOUVET, ${ }^{1 *}$ PATRICK A. D. GRIMONT,${ }^{1}$ CLAUDE RICHARD,${ }^{1}$ EVA ALDOVA, ${ }^{2}$ O. HAUSNER, ${ }^{3}$ \\ AND MARTA GABRHELOVA ${ }^{3}$ \\ Unité des Entérobactéries, Institut National de la Santé et de la Recherche Médicale Unité 199, Institut Pasteur, F-75724 \\ Paris Cedex 15, France ; Institute of Hygiene and Epidemiology, Prague, Czechoslovakia ${ }^{2}$; and Regional Public Health \\ Laboratory, České Budéjovice, Czechoslovakia ${ }^{3}$
}

\begin{abstract}
Deoxyribonucleic acid relatedness studies (S1 nuclease method) showed that 60 strains proposed as Budvicia aquatica form a homogeneous deoxyribonucleic acid hybridization group. Three strains labeled Budvicia-like were 9 to $22 \%$ related to $B$. aquatica. A total of 74 strains representing known species and genera in the Enterobacteriaceae were 0 to $8 \%$ related to $B$. aquatica. These findings support designation of Budvicia aquatica as a new genus and new species. This new species in the family Enterobacteriaceae is composed of strains which produce $\mathrm{H}_{2} \mathrm{~S}$; hydrolyze urea and $o$-nitrophenyl- $\beta$-D-galactopyranoside; do not produce acid from trehalose, D-mannose, glycerol, sucrose, maltose, and D-melibiose; do not decarboxylate lysine, ornithine, or arginine; do not produce phenylalanine deaminase; and have complex growth factor requirements. The guanine-plus-cytosine content of the deoxyribonucleic acid is $\mathbf{4 6}$ mol\%. The type strain is strain 20186HG01 (= ATCC 25567).
\end{abstract}

A new, hydrogen sulfide-producing member of the Enterobacteriaceae was recently described and named Budvicia aquatica by Aldová et al. (2). However, this name was not validated prior to the publication of the present article. The 28 strains studied by Aldová et al. (2) were isolated from freshwater in Czechoslovakia. At the same time, one of us (C.R.) was independently studying a new bacterial group that was composed of six strains isolated from stream water in Sweden and one strain isolated from a shrew in Spain and provisionally named "atypical Citrobacter" (unpublished data). After an exchange of biochemical data and strains between the Institute of Hygiene and Epidemiology (IHE) and the Institut Pasteur (IP), it became obvious that both institutes were working on the same group of microorganisms.

The purpose of the present study was to delineate Budvicia aquatica sp. nov. by using deoxyribonucleic acid (DNA)DNA hybridization and to describe formally the new genus and new species.

\section{MATERIALS AND METHODS}

Bacterial strains. The $B$. aquatica strains used in this study are listed in Table 1 . Three biochemically atypical Budvicialike strains isolated from water in Czechoslovakia and the reference strains used in the DNA relatedness study are listed in Table 2. The reference strains used have been described previously $(3,5,11)$.

DNA-DNA hybridization. We used previously described procedures to extract, purify, and shear unlabeled DNAs (4). The exact procedures used for in vitro labeling of DNA with tritium-labeled nucleotides and for hybridization experiments (S1-Trichloroacetic acid method) have been described previously (13). The temperature at which $50 \%$ of the reassociated DNA became hydrolyzable by $\mathrm{S} 1$ nuclease was determined by the method of Crosa et al. (7). The divergence value was calculated from the difference in such temperatures between the heterologous DNA reaction and the homologous DNA reaction.

$\mathbf{G}+\mathbf{C}$ content determination. The melting temperatures of $50-\mu \mathrm{g} / \mathrm{ml}$ DNA solutions in $0.1 \times \mathrm{SSC}$ buffer $(1 \times \mathrm{SSC}$ is 0.15

\footnotetext{
${ }^{*}$ Corresponding author.
}

$\mathrm{M} \mathrm{NaCl}$ plus $0.015 \mathrm{M}$ trisodium citrate) were measured with a Gilford spectrophotometer. The guanine-plus-cytosine $(\mathrm{G}+\mathrm{C})$ contents of DNAs were determined from melting temperatures by the equation of Owen et al. (18). The DNA of Escherichia coli $\mathrm{K}-12$ was used as a standard $(\mathrm{G}+\mathrm{C}$ content, $51.2 \mathrm{~mol} \%$ ). In all cases, the DNAs to be tested and Escherichia coli K-12 DNA were dialyzed against the same buffer solution in the same flask to avoid any difference in salt concentration.

Biochemical tests. All tests done at the IP were incubated at $30^{\circ} \mathrm{C}$ unless otherwise stated. Tests done at the IHE were incubated at $37^{\circ} \mathrm{C}$ unless otherwise stated. The biochemical reactions of 27 strains studied at the IHE have been published previously (2), and the data were extended to a total of 53 strains (strains $20186 \mathrm{HG}^{\mathrm{T}}{ }^{\mathrm{T}}$ [ $\mathrm{T}=$ type strain] to 23879 in Table 1) by using the same methods at the IHE. The biochemical reactions of eight strains (including strain $20186 \mathrm{HGO1}^{\mathrm{T}}$ ) were checked at the IP to evaluate betweenlaboratory variation and to add a few tests that are not currently done elsewhere. The tests done at the IP included production of gas and $\mathrm{H}_{2} \mathrm{~S}$ in glucose-lactose-iron agar (Institut Pasteur Production, Marne-la-Coquette, France), urea hydrolysis and indole production from tryptophan in urea-indole medium (Institut Pasteur Production), film method for gelatin hydrolysis (17), the $\beta$-glucuronidase test (15), the $\gamma$-glutamyltransferase test $(10)$, growth in tryptic soy broth (Institut Pasteur Production) at different temperatures, growth in peptone-water (Bacto-Peptone [Difco Laboratories, Detroit, Mich.], $10 \mathrm{~g}$; distilled water, 1 liter; $\mathrm{pH} 7$ ) containing $0,2,6$, or $8 \%(\mathrm{wt} / \mathrm{vol}) \mathrm{NaCl}$, and the VogesProskauer test using the modification of Richard (20). All other tests performed at the IP were done by using procedures described elsewhere (12).

Growth factor requirements. Attempts to determine growth factor requirements were done by using M70 minimal medium without agar (21) dispensed into tubes $(5 \mathrm{ml} /$ tube) adaptable to the Klett-Summerson colorimeter (Arthur $\mathrm{H}$. Thomas Co., Philadelphia, $\mathrm{Pa}$.) and supplemented with $0.2 \%$ (wt/vol) glucose and various combinations of growth factors in the concentrations recommended by Clowes and Hayes (6). The tubes were inoculated with about $150 \mu \mathrm{l}$ of a bacterial suspension ( 80 Klett units) in distilled water. 
TABLE 1. Reassociation of DNA from B. aquatica 23227HG26 with DNAs from other $B$. aquatica strains

\begin{tabular}{|c|c|c|}
\hline $\begin{array}{c}\text { Source of } \\
\text { unlabeled } \\
\text { DNA }\end{array}$ & Source of strain ${ }^{a}$ & $\begin{array}{c}\% \text { Relative } \\
\text { binding at } \\
60^{\circ} \mathrm{C}\end{array}$ \\
\hline $20186 \mathrm{HG}^{2} 1^{\mathrm{T}}$ & Well water, Bîlá (FM) & 99 \\
\hline 21297HG02 & Water, České Budějovice & 96 \\
\hline $21800 \mathrm{HG} 03$ & Water, Česlý Krumlov & 99 \\
\hline 21801HG04 & Water, Pelhřimov & 93 \\
\hline 21845HG05 & Well water, Bohumilice (PR) & 92 \\
\hline 21927HG06 & Well water, Dobšice (CB) & 77 \\
\hline 21929 & Well water (PR) & 91 \\
\hline 21930HG07 & Well water, Bohumilice (PR) & 93 \\
\hline 21998HG08 & Water (PE) & 90 \\
\hline 21999HG09 & Water (PE) & 94 \\
\hline 22176HG10 & Water (CB) & 94 \\
\hline 22414HG11 & Well water, Šebanov (CK) & 75 \\
\hline 22415 HG12 & Well water, Řehonice (PR) & $71(0.7)^{b}$ \\
\hline $22416 \mathrm{HG} 13$ & $\begin{array}{l}\text { Water conduit, Slavče u Trhových } \\
\text { Svinů }(\mathbf{C B})\end{array}$ & 80 \\
\hline 22529HG14 & Water conduit, Svatý Jan n/Malší (CB) & 91 \\
\hline $22530 \mathrm{HG} 15$ & Well water, Přísečná (CK) & 85 \\
\hline 23012HG17 & Water conduit, Lipí (CB) & 84 \\
\hline 23013HG18 & Water conduit, Míčovice (PR) & 87 \\
\hline 23027HG19 & Water conduit, Př́dolí (CK) & 92 \\
\hline 23149HG20 & Well water, Lčovice (PR) & 81 \\
\hline 23166HG21 & Well water, Horní Ždár (JH) & 78 \\
\hline 23167HG22 & Water conduit, Stachy (PR) & 79 \\
\hline $23168 \mathrm{HG} 23$ & Water (PR) & 96 \\
\hline 23169HG24 & Brook water, Dolní Dvořiště (CK) & 92 \\
\hline 23170 HG25 & Malše River, Pořešín (CK) & 84 \\
\hline 23227HG26 & Swimming pool, Lipiny (PB) & $100(0.0)$ \\
\hline $23236 \mathrm{HG} 27$ & Public well, Rodvínov (JH) & 97 \\
\hline 23237HG28 & Public well, Jindřichův Hradec district & 92 \\
\hline 23269 & Tributary of a swimming pool, Přibram & 97 \\
\hline 23270 & $\begin{array}{l}\text { Tributary of a swimming pool, Zalány } \\
\text { (PB) }\end{array}$ & 83 \\
\hline 23271 & $\begin{array}{l}\text { Tributary of a swimming pool, Luhy } \\
\text { (PB) }\end{array}$ & 87 \\
\hline 23272 & Well water, Bukovany (PB) & 86 \\
\hline 23273 & Well water, Bukovany (PB) & $76(1.1)$ \\
\hline 23274 & Public well, Orlov (PB) & 81 \\
\hline 23275 & Well water, Skuhrov (PB) & 91 \\
\hline 23302 & Water conduit, Svatý Jan n/Malší (CB) & $77(1.6)$ \\
\hline 23303 & Water conduit, Nový Svět (PR) & 92 \\
\hline 23367 & Well water, Čenkov (PB) & 89 \\
\hline 23436 & Well water, Přilepov (PI) & 82 \\
\hline 23471 & Stěžocký Brook, Radétice (PB) & 96 \\
\hline 23506 & Well water, Boubská (PR) & 86 \\
\hline 23516 & Besina Brook, Besina (PB) & 87 \\
\hline 23640 & Water conduit, Želnava (PR) & 91 \\
\hline 23641 & Water conduit, Stachy (PR) & 94 \\
\hline 23674 & Well water, Milín (PB) & 79 \\
\hline 23677 & Water conduit, Libníč (CB) & 82 \\
\hline 23678 & Public well, Žárovná (PR) & 88 \\
\hline 23681 & Skalice river, Mirovice (PI) & 91 \\
\hline 23706 & Well water, Plav (CB) & 93 \\
\hline 23777 & $\begin{array}{l}\text { Water conduit, Rožmberk n/Vltavou } \\
\text { (CK) }\end{array}$ & 92 \\
\hline 23795 & Pool water, Libice (PB) & 89 \\
\hline 23878 & Well water, Klínec (PW) & 92 \\
\hline 23879 & Swimming pool, Březnice (PB) & 97 \\
\hline $3-82$ & Stream water, Gruvsjön, Sweden ${ }^{c}$ & $77(2.0)$ \\
\hline $5-82$ & Stream water, Gruvsjön, Sweden & 81 \\
\hline $6-82$ & Stream water, Gruvsjön, Sweden & 87 \\
\hline $7-82$ & Stream water, Gruvsjön, Sweden & 79 \\
\hline 8-82 & Stream water, Gruvsjön, Sweden & $76(1.0)$ \\
\hline $9-82$ & Stream water, Gruvsjön, Sweden & 89 \\
\hline $5-81$ & Digestive tract of Sorex araneus, Spain ${ }^{d}$ & $86(2.0)$ \\
\hline
\end{tabular}

a Strains were isolated in Czechoslovakia unless otherwise stated. The Czechoslovakian districts, indicated by letters in parentheses, are as follows: CB, Ceské Budějovice; CK, Česky Krumlov; FM, Frýdek-Místek; JH,
Assimilation tests. Carbon source utilization tests were done at the IP by using specially manufactured API strips (API System, La Balme les Grottes, France) which contained pure carbon sources and were similar to commercial API CH, API AO, and API AA galleries (9), except that the total number of tests were limited to 99 carbon sources (these compounds are listed below). The minimal medium without growth factors (supplied by API System) was supplemented with the following 31 growth factors (final concentration in micrograms per milliliter): biotin and thiamine, 0.002; para-aminobenzoic acid, folic acid, nicotinamide, nicotinic acid, pantothenic acid, and pyridoxine, 0.08 ; riboflavin, 0.4 ; inositol, 0.8 ; sodium thiosulfate, 8 ; and L-alanine, L-arginine, L-aspartic acid, L-cysteine, L-glutamic acid, Lglutamine, glycine, histidine, isoleucine, L-leucine, L-lysine, methionine, ornithine, L-phenylalanine, proline, serine, threonine, L-tryptophan, L-tyrosine, and L-valine, 17. A total of 16 strains (strains $20186 \mathrm{HG}^{\mathrm{T}}{ }^{\mathrm{T}}, 21999 \mathrm{HG} 09$, 22529HG14, 23013HG13, 23027HG19, 23168HG23, 23227HG26, 23275, $23471,23677,23678,23706,23795,23878,3-82$, and 5-82) were tested. A $2-\mathrm{ml}$ portion of a calibrated (80-Klett unit) bacterial suspension in sterile distilled water was added to 60 $\mathrm{ml}$ of growth factor-supplemented minimal medium. The mixture was distributed into API cupules. The strips were incubated at $30^{\circ} \mathrm{C}$ and examined for growth daily for 6 days.

Production of enterobacterial common antigen. Production of enterobacterial common antigen by strain $23227 \mathrm{HG} 26$ was studied by using a previously described hemagglutination test (16).

\section{RESULTS}

DNA-DNA hybridization. The DNA relatedness results obtained with labeled reference DNA from strain 23227HG26 and unlabeled DNAs from 60 strains of $B$. aquatica are shown in Table 1. Although the type strain was not used for the labeled DNA preparation, hybridization showed the type strain and strain 23227 HG 26 to be related at the $99 \%$ level. The DNA relatedness results obtained with the same labeled DNA and DNAs from 74 other representative strains of the family Enterobacteriaceae are shown in Table 2. The S1 nuclease-resistant core (in the incubated control tubes containing only denatured labeled DNA) was calculated to be 6 $\pm 1 \%$ (mean \pm standard deviation). At $60^{\circ} \mathrm{C}$, the $B$. aquatica strains were $87.2 \pm 7.6 \%$ related to strain $23227 \mathrm{HG} 26$.

Atypical Budvidia-like strains 20125HG, 23635, and 23679 were 9 to $22 \%$ related to strain $23227 \mathrm{HG} 26$.

All other species tested were 0 to $8 \%$ related to strain 23227HG26. The divergence values between $B$. aquatica strains and strain $23227 \mathrm{HG} 26$ were less than $2^{\circ} \mathrm{C}$.

DNA base composition. The average $\mathrm{G}+\mathrm{C}$ content of the DNAs of seven strains were $46 \pm 1$ mol\%.

Phenotypic characterization. Characteristics that were common to 95 to $100 \%$ of the strains are given below in the species description. The enterobacterial common antigen was detected in strain $23227 \mathrm{HG} 26$. In semisolid nutrient agar, $91 \%$ of the strains showed motility in 2 days at $22^{\circ} \mathrm{C}$ $\left(44 \%\right.$ of the strains showed motility at $37^{\circ} \mathrm{C}$ ), and $5 \%$ of the

Jidřichův Hradec; PB, Přibram; PE, Pelhřimov; PI, Písek; RP, Prachatice; PW, Prague-West.

$b$ The values in parentheses are thermal stabilities of heteroduplexes (expressed in degrees Celsius).

${ }^{c}$ Strains from Sweden were received from Alasdair $\mathbf{H}$. Neilson.

${ }^{d}$ Received from Guillermo Prats Pastor. 
TABLE 2. Reassociation of DNA from B. aquatica 23227 HG26 with DNAs from other members of the Enterobacteriaceae

\begin{tabular}{|c|c|}
\hline Source of unlabeled DNA ${ }^{a}$ & $\begin{array}{c}\% \text { Relative } \\
\text { binding at } \\
60^{\circ} \mathrm{C}\end{array}$ \\
\hline Budvicia-like strain $20125 \mathrm{HG}$ & 9 \\
\hline Budvicia-like strain $23635 \ldots \ldots \ldots \ldots$ & 22 \\
\hline Budvicia-like strain $23679 \ldots \ldots \ldots$. . . . & 16 \\
\hline Cedecea davisae $005^{\mathrm{T}}\left(=\operatorname{CDC} 3278-77^{\mathrm{T}}\right) \ldots \ldots \ldots \ldots$ & 1 \\
\hline Cedecea sp. strain $001(=$ CDC $4853-73) \ldots \ldots \ldots \ldots$ & 2 \\
\hline Citrobacter amalonaticus $25406 \ldots \ldots \ldots \ldots \ldots \ldots$ & 0 \\
\hline Citrobacter diversus $1066-71 \ldots \ldots \ldots \ldots$ & 1 \\
\hline Citrobacter freundii $460-61 \ldots \ldots \ldots$ & 3 \\
\hline Edwardsiella tarda NCTC $10396^{\mathrm{T}} \ldots \ldots \ldots$ & 3 \\
\hline Edwardsiella tarda (atypical) strain $389-67$ & 3 \\
\hline Edwardsiella hoshinae $2-78^{\mathrm{T}} \ldots \ldots \ldots \ldots$ & 1 \\
\hline Edwardsiella ictaluri $1976-78^{\mathrm{T}} \ldots \ldots \ldots \ldots \ldots$ & 1 \\
\hline Enterobacter aerogenes $\mathrm{Al}^{\mathrm{T}}\left(=\mathrm{ATCC} 13048^{\mathrm{T}}\right) \ldots \ldots$ & 1 \\
\hline Enterobacter agglomerans $\mathrm{E} 20^{\mathrm{T}}\left(=\mathrm{NCTC} 9381^{\mathrm{T}}\right) \ldots \ldots$ & 3 \\
\hline Enterobacter agglomerans II $3123-70 \ldots \ldots \ldots \ldots \ldots$ & 0 \\
\hline Enterobacter agglomerans III 1429-71 .......... & 3 \\
\hline Enterobacter agglomerans IV 1741-71 ... & 2 \\
\hline Enterobacter agglomerans $\mathrm{V} 3482-71 \ldots \ldots \ldots \ldots \ldots$ & 4 \\
\hline Enterobacter agglomerans VI 6070-69 ...... & 1 \\
\hline Enterobacter agglomerans VII 6003-71 .......... & 2 \\
\hline Enterobacter agglomerans VIII $5422-69 \ldots \ldots \ldots \ldots$ & 0 \\
\hline Enterobacter agglomerans IX 4388-71 ........... & 0 \\
\hline Enterobacter agglomerans X 1600-71 ........... & 5 \\
\hline Enterobacter agglomerans XI 5378-71 . . . . . . . . & 0 \\
\hline Enterobacter agglomerans XII $219.71 \ldots \ldots \ldots \ldots$ & 4 \\
\hline Enterobacter agglomerans XIII $1645-71 \ldots \ldots \ldots \ldots \ldots$ & 1 \\
\hline Enterobacter amnigenus $7879 \ldots \ldots \ldots \ldots \ldots$ & 3 \\
\hline Enterobacter cloacae $1347-71 \ldots \ldots \ldots \ldots \ldots \ldots \ldots$ & 0 \\
\hline Enterobacter gergoviae $2-78 \ldots \ldots \ldots \ldots \ldots \ldots \ldots$ & 2 \\
\hline Enterobacter intermedium $77-127(=$ ATCC 33422$) \ldots$. & 1 \\
\hline Enterobacter sakazakii $4562-70$ (= ATCC 29544) ....... & 1 \\
\hline 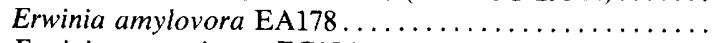 & 3 \\
\hline 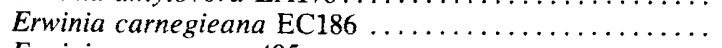 & 2 \\
\hline Erwinia carotovora $495 \ldots \ldots \ldots$ & 2 \\
\hline Erwinia chrysanthemi SR32.......... & 3 \\
\hline Erwinia cypripedii EC $155 \ldots \ldots \ldots \ldots$ & 4 \\
\hline Erwinia mallotivora $2851^{\mathrm{T}}$ & 1 \\
\hline Erwinia nigrifluens EN104... & 2 \\
\hline Erwinia rhapontici ER106 ... & 2 \\
\hline Erwinia rubrifaciens ER $105 \ldots \ldots \ldots$ & 2 \\
\hline Erwinia salicis $\mathrm{ES} 102 \ldots \ldots \ldots \ldots \ldots \ldots \ldots \ldots \ldots \ldots$ & 1 \\
\hline Escherichia blattae $9005-74^{\mathrm{T}}\left(=\mathrm{ATCC} 29907^{\mathrm{T}}\right) \ldots \ldots \ldots$ & 1 \\
\hline Escherichia coli $\mathrm{K}-12 \ldots \ldots \ldots \ldots \ldots \ldots \ldots \ldots$ & 1 \\
\hline Ewingella americana $1468-78^{\mathrm{T}}\left(=\mathrm{ATCC} 33852^{\mathrm{T}}\right) \ldots \ldots$ & 4 \\
\hline Hafnia alvei $329-73 \ldots \ldots \ldots \ldots \ldots \ldots \ldots$ & 2 \\
\hline Klebsiella oxytoca $13182^{\mathrm{T}}$ & 0 \\
\hline Klebsiella pneumoniae $2 \ldots$ & 0 \\
\hline Klebsiella sp. strain $4241-72 \ldots \ldots \ldots \ldots \ldots \ldots$ & 1 \\
\hline Kluyvera ascorbata $1.79(=$ ATCC 14236$) \ldots \ldots \ldots \ldots$ & 1 \\
\hline 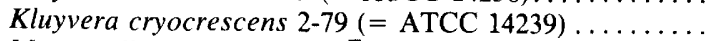 & 2 \\
\hline Morganella morganii $25830^{\mathrm{T}} \ldots \ldots \ldots \ldots \ldots \ldots \ldots \ldots$ & 4 \\
\hline Obesumbacterium proteus $4302-74$. & 0 \\
\hline Proteus mirabilis PR14 ........... & 2 \\
\hline Proteus myxofaciens $19692^{\mathrm{T}} \ldots \ldots \ldots$ & 0 \\
\hline Proteus rettgeri 1163 ( = ATCC 29944). & 0 \\
\hline Proteus vulgaris PR1 $\ldots \ldots \ldots \ldots \ldots \ldots \ldots$ & 0 \\
\hline Providencia stuartii $2896-68^{\mathrm{T}}\left(=\right.$ ATCC $\left.29914^{\mathrm{T}}\right)$. & 1 \\
\hline Rahnella aquatilis $77-115^{\mathrm{T}}\left(=\right.$ ATCC $\left.33071^{\mathrm{T}}\right) \ldots$ & 2 \\
\hline Salmonella typhimurium $\mathrm{LT} 2 \ldots \ldots \ldots \ldots$ & 1 \\
\hline Serratia grimesii $3692 \ldots \ldots \ldots \ldots \ldots$ & 3 \\
\hline Serratia grimesii $503^{\mathrm{T}}\left(=\right.$ ATCC $\left.14460^{\mathrm{T}}\right) \ldots$ & 3 \\
\hline Serratia marcescens $504^{\mathrm{T}}\left(=\right.$ ATCC $\left.13880^{\mathrm{T}}\right)$ & 3 \\
\hline Serratia odorifera $1073^{\mathrm{T}}\left(=\right.$ ATCC $\left.33077^{\mathrm{T}}\right) \ldots$ & 5 \\
\hline Shigella boydii $1610-55 \ldots \ldots \ldots \ldots \ldots \ldots$ & 1 \\
\hline Tatumella ptyseos $\mathrm{H} 3 \ldots$ & 3 \\
\hline Xenorhabdus luminescens $\mathrm{Hb}^{\mathrm{T}}$... & 5 \\
\hline Xenorhabdus luminescens NC-19. & 8 \\
\hline
\end{tabular}

TABLE 2-Continued

\begin{tabular}{|c|c|}
\hline Source of unlabeled DNA ${ }^{a}$ & $\begin{array}{c}\% \text { Relative } \\
\text { binding at } \\
60^{\circ} \mathrm{C}\end{array}$ \\
\hline Xenorhabdus sp. strain $286 \ldots \ldots \ldots \ldots$ & 8 \\
\hline Xenorhabdus nematophilus CCEB $786^{\mathrm{T}} \ldots \ldots \ldots \ldots$ & 5 \\
\hline Yersinia enterocolitica $614 \ldots \ldots \ldots \ldots \ldots \ldots \ldots$ & 1 \\
\hline Yersinia frederiksenii CIP $8029 \ldots \ldots \ldots \ldots \ldots \ldots$ & 5 \\
\hline Yersinia intermedia CIP $8028 \ldots \ldots \ldots \ldots \ldots \ldots$ & 6 \\
\hline Yersinia kristensenii CIP $8030 \ldots \ldots \ldots \ldots \ldots \ldots \ldots$ & 5 \\
\hline Yersinia pseudotuberculosis $\mathrm{P} 105 \ldots \ldots \ldots \ldots \ldots$ & 2 \\
\hline 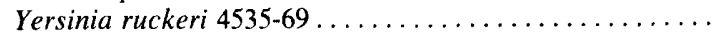 & 1 \\
\hline
\end{tabular}

a ATCC, American Type Culture Collection, Rockville, Md.; CCEB Culture Collection of Entomopathogenic Bacteria, Prague, Czechoslovakia; CDC, Centers for Disease Control, Atlanta, Ga.; NCTC, National Collection of Type Cultures, London, England.

strains showed motility in 3 to 20 days at $22^{\circ} \mathrm{C}$ ( $11 \%$ of the strains showed motility in 3 to 20 days at $37^{\circ} \mathrm{C}$ ). The methyl red test yielded variable results. At the IHE, 22 and $31 \%$ of the strains gave positive methyl red tests at 37 and $22^{\circ} \mathrm{C}$, respectively. At the IP, $50 \%$ of the strains gave positive methyl red tests at $30^{\circ} \mathrm{C}$. No hydrolysis of gelatin was detected at the IHE (nutrient gelatin method), whereas seven strains tested at the IP hydrolyzed gelatin as determined by the film method in 1 to 5 days. Gas was not produced from glucose in triple-sugar-iron agar (IHE) or glucose-lactose-iron agar (IP), but weak production of gas was detected in Durham tubes with peptone-water and glucose with some strains (five of eight tested at the IP). Production of acid from lactose was also variable. At the IHE, $9 \%$ of the strains produced acid from lactose in 2 days, and $67 \%$ produced acid in 3 to 20 days. At the IP (eight strains checked), five strains produced acid from lactose in 2 days, and seven strains produced acid in 3 to 6 days. Acid was produced from rhamnose by $79 \%$ of the strains in 2 days (IHE) and $18 \%$ of the strains in 3 to 20 days. The eight strains tested at the IP produced acid from rhamnose. $o$-Nitrophenyl- $\beta$-D-galactopyranoside was hydrolyzed by $98 \%$ of the strains tested at the IHE and by all eight strains tested at the IP.

The growth factor requirements were found to be complex. An absolute requirement for nicotinic acid was observed. In tubes, moderate growth $(23$ Klett units after 2 days) was obtained when $\mathbf{M 7 0}$ minimal medium containing glucose was supplemented with nicotinic acid $(0.08 \mu \mathrm{g} / \mathrm{ml})$ and L-cysteine, threonine, aspartic acid, and glycine (17 $\mu \mathrm{g} / \mathrm{ml}$ each). No single vitamin or amino acid added to the growth factor mixture described above improved growth significantly. However, good growth $(52 \mathrm{Klett}$ units after 2 days) was obtained when M70 minimal medium containing glucose was supplemented with the 31 growth factors listed above (factors used in assimilation tests).

The 16 strains submitted to assimilation tests utilized 29 substrates and failed to utilize 54 substrates (see below). Variable results were obtained with the following 16 substrates (the numbers of strains positive are given in parentheses): citrate (15), L-proline (15), lactose (12), D-fructose (11), L-tyrosine (10), glycine (8), D-melibiose (2), betaine (2), trans-aconitate (2), adonitol (1), D-malate (1), xylitol (1), D-lyxose (1), L-tartrate (1), acetate (1), and propionate (1).

\section{DISCUSSION}

The strains of $B$. aquatica have properties (2) fitting the description of the family Enterobacteriaceae (8). Production 
of the enterobacterial common antigen is a confirmatory test of family assignation $(16,19)$.

The $G+C$ content of $B$. aquatica DNA is on the low end of the range reported for the Enterobacteriaceae (38 to 60 mol\%). This $\mathrm{G}+\mathrm{C}$ content was reported earlier as 51 to 54 mol\% (2). However, no control DNA was included in these tests (E.A.). In all of the $\mathrm{G}+\mathrm{C}$ determinations described in the present paper, the $B$. aquatica DNA melting curves started and ended at a lower temperature than the Escherichia coli melting curves did, and the calculated thermal denaturation values for $B$. aquatica (all experiments and all DNAs tested) were lower than the Escherichia coli K-12 thermal denaturation values.

The DNA relatedness experiments showed that the 60 strains of $B$. aquatica form a single DNA hybridization group clearly distinct from 74 known DNA relatedness groups in the family Enterobacteriaceae. Thus, B. aquatica is a good genomic species. Apart from Budvicia-like strains $20125 \mathrm{HG}, 23635$, and 23679 , the genus most closely related to $B$. aquatica is Xenorhabdus. The $8 \%$ homology (S1 method) between $B$. aquatica and Xenorhabdus spp. would probably correspond to about $28 \%$ homology if the hydroxyapatite method were used (13). However, there is too little phenotypic relatedness, if any, between Budvicia (2) and Xenorhabdus $(1,14)$ to think of transferring Budvicia to the genus Xenorhadbus. Thus, the results of DNA relatedness studies support the designation of a new genus, Budvicia. In addition, this genomic group possesses biochemical characteristics which allow unambiguous distinction from other genera and species in the Enterobacteriaceae (2).

A practical reason to recognize $B$. aquatica as an environmental bacterial species is that it might be misidentified as a Yersinia (strains from Sweden were received as $\mathrm{H}_{2} \mathrm{~S}$-positive Yersinia), Citrobacter, or possibly Salmonella or Edwardsiella species.

To recognize the priority of three authors in the delineation of the new genus and species, we propose the following citations of names: Budvicia Aldová, Hausner, and Gabrhelová in Bouvet, Grimont, Richard, Aldová, Hausner, and Gabrhelová 1985; and Budvicia aquatica Aldová, Hausner, and Gabrhelová in Bouvet, Grimont, Richard, Aldová, Hausner, and Gabrhelová 1985.

Description of Budvicia gen. nov. Budvicia (Bud. vi' ci. a. L. fem. n. Budvicia derived from Budvicium, the Latin name of the city České Budějovice, where the bacterium was first isolated) cells are gram-negative, nonsporeforming, non-encapsulated, straight rods with peritrichous flagella (when grown at $22^{\circ} \mathrm{C}$ ). Members of the genus conform to the definition of the family Enterobacteriaceae (8). Facultatively anaerobic; glucose fermenters; nitrate reducers. Oxidase test negative. Small colonies are produced on nutrient agar. Growth occurs between 4 and $37^{\circ} \mathrm{C}$, but not at $42^{\circ} \mathrm{C}$. No growth occurs in $\mathrm{KCN}$ medium. $\mathrm{H}_{2} \mathrm{~S}$ produced; urea hydrolyzed. Indole not produced. Tryptophan and phenylalanine not deaminated. Lysine, arginine, and ornithine not decarboxylated. Voges-Proskauer test negative. Acid not produced from maltose, D-mannose, glycerol, and trehalose. Esculin not hydrolyzed. Gluconate test negative. $o$ Nitrophenyl- $\beta$-D-galactopyranoside hydrolyzed. Extracellular enzymes (lipase, Tween esterase, amylase, deoxyribonuclease, gelatinase [tube method]) not produced (in 6 days) or weakly produced (gelatinase [film method]). No growth on Simmons citrate or Trabulsi acetate. Growth factor requirements are complex. The enterobacterial common antigen is produced. The $\mathrm{G}+\mathrm{C}$ content of the DNA is about $46 \mathrm{~mol} \%$. The type species is Budvicia aquatica.
Description of Budvicia aquatica sp. nov. Budvicia aquatica (a. qua' ti. ca. L. fem. adj. aquatica living in water) cells are gram-negative, nonsporeforming, non-encapsulated, straight rods with peritrichous flagella (when grown at $22^{\circ} \mathrm{C}$ ). Nonmotile strains occur. The species conforms to the definition of the Enterobacteriaceae (8).

All strains grow on nutrient agar, producing small colonies about $0.1 \mathrm{~mm}$ in diameter after 24 or $48 \mathrm{~h}$ at $37^{\circ} \mathrm{C}$ or about 0.5 $\mathrm{mm}$ in diameter after $24 \mathrm{~h}$ and $1.5 \mathrm{~mm}$ in diameter after $48 \mathrm{~h}$ at $30^{\circ} \mathrm{C}$. The colonies are translucent and have smooth, entire edges. Facultatively anaerobic. All strains grow in 1 day at $4,10,30$ or $37^{\circ} \mathrm{C}$ in tryptic soy broth and at $30^{\circ} \mathrm{C}$ in peptone-water containing 0 to $4 \% \mathrm{NaCl}$. Growth in peptonewater containing $6 \% \mathrm{NaCl}$ occurs in 2 days. No growth at $42^{\circ} \mathrm{C}$ (in either tryptic soy broth or nutrient broth). Growth occurs on MacConkey agar.

Catalase produced. Oxidase not produced. Nitrates reduced to nitrites. No growth occurs in KCN medium. Tetrathionate reduced. $\mathrm{H}_{2} \mathrm{~S}$ produced in triple-sugar-iron agar or in glucose-lactose-iron agar. Urea hydrolyzed in urea-indole medium and Christensen medium. $o$-Nitrophenyl- $\beta$-D-galactopyranoside hydrolyzed. $\gamma$-Glutamyltransferase test positive; $\beta$-glucuronidase test negative. Indole not produced in peptone-water or urea-indole medium. Tryptophan and phenylalanine not deaminated. Lysine, arginine, and ornithine not decarboxylated (Møller medium). Tributyrin, Tween 80 , starch, and DNA not hydrolyzed within 6 days. Gelatin slowly hydrolyzed (film method, 2 to 5 days) or not hydrolyzed (tube method). Glucose fermented with little or no production of gas. Voges-Proskauer test negative $\left(22,30\right.$, or $\left.37^{\circ} \mathrm{C}\right)$. Methyl red test positive or negative. Acid produced (in 2 days) in peptone-water from glucose, L-arabinose, galactose, galacturonate, xylose, and mucate. Most strains produce acid from rhamnose. Production of acid from D-mannitol is delayed ( 1 to 3 days in peptone-water at the IP) and may depend upon the method used (no acid was produced from D-mannitol in tests done at the IHE). Acid not produced (in 2 days) from adonitol, cellobiose, dulcitol, inositol, maltose, mannose, glycerol, raffinose, salicin, sorbitol, sorbose, sucrose, trehalose, Dmelezitose, and D-melibiose. Acid produced (1 to 4 days) or not produced from lactose. $\beta$-Xylosidase test positive or negative. Esculin not hydrolyzed. Gluconate test negative.

No growth on Simmons citrate or Trabulsi acetate. Growth factor requirements are complex; nicotinic acid is absolutely required, and a combination of amino acids (including L-cysteine, threonine, aspartic acid, and glycine) is necessary to yield appreciable growth.

The following compounds are used as sole carbon and energy sources (in a minimal medium supplemented with 31 growth factors): $N$-acetylglucosamine, L-arabinose, D-arabitol, L-aspartate, meso-erythritol, fumarate, galactose, galacturonate, gluconate, D-glucose, glucuronate, L-glutamate, DL-glycerate, glycerol, 2-ketogluconate, 5-ketogluconate, DLlactate, L-malate, D-mannitol, mucate, 2-oxoglutarate, pyruvate, rhamnose, ribose, L-serine, succinate, D-tartrate, meso-tartrate, and D-xylose. The following compounds are not used as sole carbon and energy sources: D-alanine, L-alanine, $\beta$-alanine, 2 -aminobenzoate, DL-4-aminobutyrate, DL-5-aminovalerate, L-arabitol, benzoate, butyrate, caprate, caprylate, D-cellobiose, dulcitol, esculin, ethanolamine, Lfucose, $\beta$-gentiobiose, glucosamine, glutarate, heptanoate, histamine, L-histidine, 3-hydroxybenzoate, 4-hydroxybenzoate, DL-3-hydroxybutyrate, myo-inositol, itaconate, malonate, maltitol, maltose, D-mannose, D-melezitose, L-methionine, $\alpha$-methyl-D-glucoside, 3-methyl-D-glucose, $\beta$ - 
methyl-D-glucoside, $\alpha$-methyl-D-mannoside, phenylacetate, putrescine, quinate, D-raffinose, salicin, sarcosine, sorbitol, $\mathrm{L}$-sorbose, sucrose, D-tagatose, trehalose, trigonelline, tryptamine, D-tryptophan, L-tryptophan, and D-turanose. The $\mathrm{G}+\mathrm{C}$ content of the DNA is $46 \mathrm{~mol} \%$.

Isolated mostly from water (drinking or river water) and also from wild small mammals. No strain has yet been identified as involved in a human, animal, or plant disease.

The type strain is strain $20186 \mathrm{HG} 01$ (= ATCC 25567).

Description of the type strain. Strain $20186 \mathrm{HG}_{01}^{\mathrm{T}}$ has all of the characteristics given above for the species. In addition, this strain is motile and $\beta$-xylosidase positive, hydrolyzes gelatin (film method) in 3 days, produces a small amount of gas from glucose in peptone-water with a Durham tube, and produces acid from rhamnose (in 1 day), lactose (in 2 days), and D-mannitol (in 2 days). The following substrates are utilized by strain $20186 \mathrm{HG}^{\mathrm{T}} \mathrm{1}^{\mathrm{T}}$ (API strips with carbon sources; minimal medium supplemented with 31 growth factors): D-fructose, lactose, D-lyxose, citrate, glycine, Ltyrosine, L-proline, and propionate. The following substrates are not utilized: adonitol, D-malate, trans-aconitate, betaine, L-tartrate, and acetate.

\section{ACKNOWLEDGMENTS}

Thanks are due to Alasdair H. Neilson and Guillermo Prats Pastor for kindly providing strains included in this study. We acknowledge the excellent technical assistance of Elisabeth Ageron for the phenotypic study done at the IP.

\section{LITERATURE CITED}

1. Akhurst, R. J. 1983. Taxonomic study of Xenorhabdus, a genus of bacteria symbiotically associated with insect-pathogenic nematodes. Int. J. Syst. Bacteriol. 33:38-45.

2. Aldová, E., O. Hausner, M. Gabrhelová, J. Schindler, P. Petrăs, and $H$. Braná. 1983. A hydrogen sulfide producing gram-negative rod from water. Zentralbl. Bakteriol. Parasitenkd. Infektionskr. Hyg. Abt. 1 Orig. Reihe A 254:95-108.

3. Brenner, D. J., J. J. Farmer III, G. R. Fanning, A. G. Steigerwalt, P. Klykken, H. G. Wathen, F. W. Hickman, and W. H Ewing. 1978. Deoxyribonucleic acid relatedness of Proteus and Providencia species. Int. J. Syst. Bacteriol. 28:269-282.

4. Brenner, D. J., A. C. McWhorter, J. K. Leete-Knudson, and A. G. Steigerwalt. 1982. Escherichia vulneris: a new species of Enterobacteriaceae associated with human wounds. J. Clin. Microbiol. 15:1133-1140.

5. Brenner, D. J., A. G. Steigerwalt, P. D. Falcaõ, R. E. Weaver, and G. R. Fanning. 1976. Characterization of Yersinia enterocolitica and Yersinia pseudotuberculosis by deoxyribonucleic acid hybridization and by biochemical reactions. Int. J. Syst. Bacteriol. 26:180-194.

6. Clowes, R. C., and W. Hayes. 1968. Experiments in microbial genetics. Blackwell Scientific Publications, Oxford.
7. Crosa, J. H., D. J. Brenner, and S. Falkow. 1973. Use of a single-strand-specific nuclease for analysis of bacterial and plasmid deoxyribonucleic acid homo- and heteroduplexes. J. Bacteriol. 115:904-911.

8. Edwards, P. R., and W. H. Ewing. 1972. Identification of Enterobacteriaceae, 3rd ed. Burgess Publishing Co., Minneapolis.

9. Gavini, F., D. Izard, H. Leclerc, M. Desmonceaux, and J. P. Gayral. 1980. Carbon source assimilation tests: comparison between a conventional method and a microtechnic (API), in study of Enterobacteriaceae. Zentralbl. Bakteriol. Parasitenkd. Infektionskr. Hyg. Abt. 1 Orig. Reihe C 1:182-187.

10. Giammanco, G., J. Buissière, M. Toucas, G. Brault, and L. Le Minor. 1980. Intérêt taxonomique de la recherche de la $\gamma$ glutamyltransférase chez les Enterobacteriaceae. Ann. Microbiol. (Paris) 131A:181-187.

11. Grimont, P. A. D., J. J. Farmer III, F. Grimont, M. A. Asbury, D. J. Brenner, and C. Deval. 1983. Ewingella americana gen. nov., sp. nov., a new Enterobacteriaceae isolated from clinical specimens. Ann. Microbiol. (Paris) 134A:39-52.

12. Grimont, P. A. D., F. Grimont, H. L. C. Dulong de Rosnay, and P. H. A. Sneath. 1977. Taxonomy of the genus Serratia. J. Gen. Microbiol. 98:39-66.

13. Grimont, P. A. D., M. Y. Popoff, F. Grimont, C. Coynault, and M. Lemelin. 1980. Reproductibility and correlation study of three deoxyribonucleic acid hybridization procedures. Curr. Microbiol. 4:325-330.

14. Grimont, P. A. D., A. G. Steigerwalt, N. Boemare, F. W. Hickman-Brenner, C. Deval, F. Grimont, and D. J. Brenner. 1984. Deoxyribonucleic acid relatedness and phenotypic study of the genus Xenorhabdus. Int. J. Syst. Bacteriol. 34:378-388.

15. Le Minor, L., J. Buissière, G. Novel, and M. Novel. 1978. Relation entre le sérotype et l'activité $\beta$-glucuronidasique chez les Salmonella. Ann. Microbiol. (Paris) 129B:155-165.

16. Le Minor, L., A.-M. Chalon, and M. Véron. 1972. Recherche sur la présence de l'antigène commun des Enterobacteriaceae (antigène Kunin) chez les Yersinia, Levinea, Aeromonas et Vibrio. Ann. Inst. Pasteur Paris 123:761-774.

17. Le Minor, L., and M. Piéchaud. 1963. Note technique. Une méthode rapide de recherche de la protéolyse de la gélatine. Ann. Inst. Pasteur Paris 105:792-794.

18. Owen, R. J., L. R. Hill, and S. P. Lapage. 1969. Determination of DNA base compositions from melting profiles in dilute buffers. Biopolymers 7:503-516.

19. Ramia, S., E. Neter, and D. J. Brenner. 1982. Production of enterobacterial common antigen as an aid to classification of newly identified species of the families Enterobacteriaceae and Vibrionaceae. Int. J. Syst. Bacteriol. 32:395-398.

20. Richard, C. 1972. Méthodes rapides pour l'étude des réactions de rouge de méthyle et Voges-Proskauer. Ann. Inst. Pasteur Paris 122:979-986.

21. Véron, M. 1975. Nutrition et taxonomie des entérobactéries. I. Méthode d'étude des auxanogrammes. Ann. Microbiol. (Paris) 126A:267-274. 